\title{
Effects of Beta-Carboline Alkaloids of Peganum Harmala on Induced Rat lleum Contractions
}

\author{
Amjad T. Shatarat ${ }^{1, *}$, Sawsan Abuhamdah ${ }^{2,3}$, Eman Alefishat ${ }^{3,4}$, Mohamed K. Al-Essa ${ }^{5}$, Rima Altaweel R', Faisal \\ Mohammed $^{5}$, Darwish Badran', Hanan Jafar'
}

Amjad T. Shatarat ${ }^{1, *}$, Sawsan

Abuhamdah ${ }^{2,3}$, Eman Alefishat ${ }^{3,4}$,

Mohamed Al-Essa ${ }^{5}$, Rima

Altaweel R' ${ }^{1}$, Faisal Mohammed ${ }^{5}$,

Darwish Badran', Hanan Jafar ${ }^{1}$

'Department of Anatomy and Histology,

School of Medicine, The University of Jordan, Amman, JORDAN.

${ }^{2}$ College of Pharmacy, Al-Ain University, Abu Dhabi, UAE.

${ }^{3}$ Department of Biopharmaceutics and Clinical Pharmacy, School of Pharmacy, The University of Jordan, Amman, JORDAN. ${ }^{4}$ Department of Pharmacology, College of Medicine and Health Sciences, Khalifa University, UAE.

${ }^{5}$ Department of Physiology and Biochemistry, School of Medicine, The University of Jordan, JORDAN.

\section{Correspondence}

\section{Dr. Amjad Shatarat}

Department of Anatomy and Histology,

School of Medicine, The University of

Jordan, Amman 11942, JORDAN.

Phone: +926-6-5355000

E-mail: a.shatarat@ju.edu.jo

History

- Submission Date: 13-11-2019;

- Review completed: 05-12-2019.

- Accepted Date: 03-01-2020.

DOI : $10.5530 / p j .2020 .12 .40$

Article Available online

http://www.phcogj.com/v12/i2

\section{Copyright}

(C) 2020 Phcogj.Com. This is an openaccess article distributed under the terms of the Creative Commons Attribution 4.0 International license.

\section{ABSTRACT}

Peganum harmala L., Zygophyllaceae popularly known as Wild Syrian rue, a well-known plant in folk medicine for many pharmacological uses including antispasmodic activity. Chemical composition of the plant showed that the most important constituents of this plant are betacarboline alkaloids such as harmalol, harmaline, and harmine. In this work, we aimed to evaluate the effects of these three major harmala alkaloids on induced rat ileum contractions, induced by acetylcholine, $\mathrm{BaCl}_{2}$ and $\mathrm{KCl}$. Of these three harmala alkaloids, harmalol and harmaline produced a concentration-dependent spasmolytic activity, which was found to be reversible (i.e. disappeared after tissue wash-up. Both alkaloids inhibited acetylcholine and $\mathrm{KCl}$-induced ileum contractions but $\mathrm{BaCl}_{2}$-induced contractions were only inhibited by harmalol but not harmaline. Harmine did not show any inhibitory activity.

Key words: Peganum Hermala L; $\beta$-Carbolines alkaloids; Harmine; Harmaline; Harmalol; Rat; lleum; Spasmolytic.

\section{INTRODUCTION}

Peganum harmala L. also known as Syrian rue, that belongs to the Family of Zygophyllaceae, is a perennial herbaceous, glabrous plant, which grows in a dry grassland with high temperature in the summer and low temperature in the winter (or grows in a desert climate) and sandy soils. It may grow up to $100 \mathrm{~cm}^{1}$ with white flowers between June and August. The flowers are single, small with five petals. Each flower tends to develop into a fruit ${ }^{2}$, the fruits are green and change to orange-brown when mature, the fruits are also preserved in a capsule with three chambers, each capsule contains more than 50 small black-brown triangular seeds. ${ }^{2,3}$

Peganum harmala L. is widely used as a medicinal plant that can be found in North Africa, Mediterranean, the Middle East, Pakistan, India and southern parts of Iran, and recently has also been found to grow in Australia and southwest of America. ${ }^{3}$

Through history, the usage of $P$. harmala was traced, for example, in west Asia this plant used as a talisman against voodoo and evil eye ${ }^{4}$, in the middle east it is used as psychoactive substance for spiritual experiences and it is also found to be used as a hallucinogenic aid by ancient Persian and Indian. ${ }^{5}$ In traditional medicine, $P$. harmala has been used for the treatment of different conditions, like asthma, lumbago, colic, jaundice and to stimulate menstrual flow. ${ }^{6}$ However, in recent pharmaceutical studies, $P$. harmala found to have an antispasmodic ${ }^{7}$, antimicrobial, emmenaguage and abortive effects ${ }^{8}$, blocking different types of intestinal calcium channels ${ }^{9}$, mono amine oxidase inhibition and anti-depressant effect ${ }^{10,11}$, analgesic ${ }^{12}$, vasorelaxant activity against phenylephrine- induced contraction of isolated rat aorta ${ }^{13}$, antiplatelet aggregation effects ${ }^{14}$, hallucinergic, and antineoplasm effect. ${ }^{15-18}$

The active pharmacological compounds of $P$ harmala are alkaloids, $\beta$-carbolines (like harmine, harmaline, harman and harmalol) which can be found in high levels in seeds, roots and least found in leaves and stems. ${ }^{16}$ Quinazoline alkaloids (such as vasicine and vasicinone) have also been identified. ${ }^{2}$ The major alkaloids of $P$. harmala can be found in seeds and roots, harmaline (also known as harmidine) and harmine (banisterine) have the same pharmacological action but harmine (banisterine) is considered as less toxic. The active alkaloids of harmal seeds are the monoamine oxidase inhibitor A (MAOI-A) compounds, for this reason the popularity of this plant among western psychonauts as a psychoactive drug. ${ }^{17}$

Previous study suggested that $P$. harmala alkaloids, $\beta$-carbolines (harmine, harmaline, and harmalol) have a relaxant effect on smooth muscle of the trachea contracted by $\mathrm{KCl}^{19}$, in another study, $\beta$-carbolines (harmaline) found to inhibit acetylcholine induced ileal contraction. ${ }^{20}$

Therefore, the present study was carried out to examine the spasmolytic activity of the three major harmala alkaloids i.e., harmine, harmaline, and harmalol on the isolated rat ileum preparations induced by different stimulants like, acetylcholine (Ach), $\mathrm{BaCl}_{2}$ and $\mathrm{KCl}$.

\section{MATERIALS AND METHODS}

\section{Drugs and chemicals}

All chemicals used in this study were of analytical grade and were obtained from St. Louis, MO, USA. 
Harmaline, harmine, harmalol, acetylcholine chloride ( $\geq 98.0 \%$ purity) were also purchased from Sigma Aldrich and a stock solutions was prepared on daily basis. Kreb's solution was prepared fresh, just before the experiment and consisted of (in $\mathrm{mm}$ ): $\mathrm{NaCl}$ (118.1), $\mathrm{KCl}$ (4.7), $\mathrm{CaCl}_{2}$ (2.5), $\mathrm{MgSO}_{4}$ (1.2), $\mathrm{NaHCO}_{3}(25)$ and glucose (5.6).

\section{Experimental animals}

Three-month-old male Wister rats (250-300 g) were obtained from the animal facilities of the Faculty of Medicine, The University of Jordan. The animals were housed under standard husbandry conditions, which included an ambient temperature $20-22{ }^{\circ} \mathrm{C}$ and a $12 / 12 \mathrm{~h}$ light/dark cycle, with free access to food and water. All animal experiments were conducted in concordance with the University of Jordan's "Regulations and Ethical Guidelines for the Care and Use of Laboratory Animals".

\section{lleum-tissue isolation and sample mounting}

Four segments of each rat ileum were used on each day of the experiment. The animals were anesthetized by ether and sacrificed. The abdominal cavity was opened by a midline incision aseptically. One $\mathrm{cm}$ from the flexure of the intestine was cut and the segment of the ileum was dissected out and placed in oxygenated Krebs solution at ( $\mathrm{pH} 7.4)$ at room temperature. The ileum tissue was carefully flushed out with freshly prepared Krebs solution maintained at $37^{\circ} \mathrm{C}$ bubbled with gas mixture of $95 \% \mathrm{O}_{2}$ and $5 \% \mathrm{CO}_{2}$. From a resting tension of $2 \mathrm{~g}$, isotonic contractions, elicited by $\mathrm{KCl}, \mathrm{BaCl}_{2}$ and Ach, were recorded using Radnoti, 159901A, the isometric force transducers with computerized data acquisition system. Before the start of the experiment, all preparations were allowed to equilibrate for at least 30-45 min, during which Krebs solution was replaced twice. To study the spasmolytic effect of harmaline, harmine or harmalol, contractile agents such as AChchloride, potassium chloride $(\mathrm{KCl})$ or $\mathrm{BaCl}_{2}$ were added according to Shatarat et al. (2014), directly to the organ bath in volumes usually not exceeding $5 \%$ of the bath volume ( $20 \mathrm{ml}$ organ bath). The ACh-chloride at $\left(3 \times 10^{-5} \mathrm{M}\right)$, potassium chloride $\mathrm{KCl}(60 \mathrm{mM})$ or $\mathrm{BaCl}_{2}(5 \mathrm{mM})$ were added to the organ bath in the absence (control) or in the presence of various concentrations of harmaline, harmine, or harmalol.

\section{Statistical analysis}

Mean and standard error of the mean (S.E.M.) values were calculated for each group of results and the significance of difference between the means was calculated using one-way analysis of variance (ANOVA) followed by Dunnett's test. Differences were considered statistically significant when $\mathrm{P}<0.05$. Harmaline, harmine or harmalol -evoked spasmolytic effect were expressed as a percentage of relaxation from spasmogen induced plateau contraction from the concentration response curve by data fitting using GraphPad Prism version 5.02 for Windows (GraphPad Software, San Diego, CA, USA).

\section{RESULTS}

\section{Effects of harmaline, harmine or harmalol on $\mathrm{ACh}$ induced ileum contraction}

A single application of Ach $\left(3 \times 10^{-5} \mathrm{M}\right)$ evoked $100 \%$ contraction (Figure 1). Harmine had no significant effect on baseline tension but harmaline and harmalol inhibited the Ach induced contractile responses, harmaline at $5 \mu \mathrm{M}$ and $10 \mu \mathrm{M}\left({ }^{*} \mathrm{P}<0.05\right)$ and harmalol at 5 and $10 \mu \mathrm{M}\left({ }^{* * *} \mathrm{P}<0.0001\right)$ respectively. These inhibitory effects could be seen within 10 min of contact with the tissue and were maintained as long as these alkaloids present in the bath.

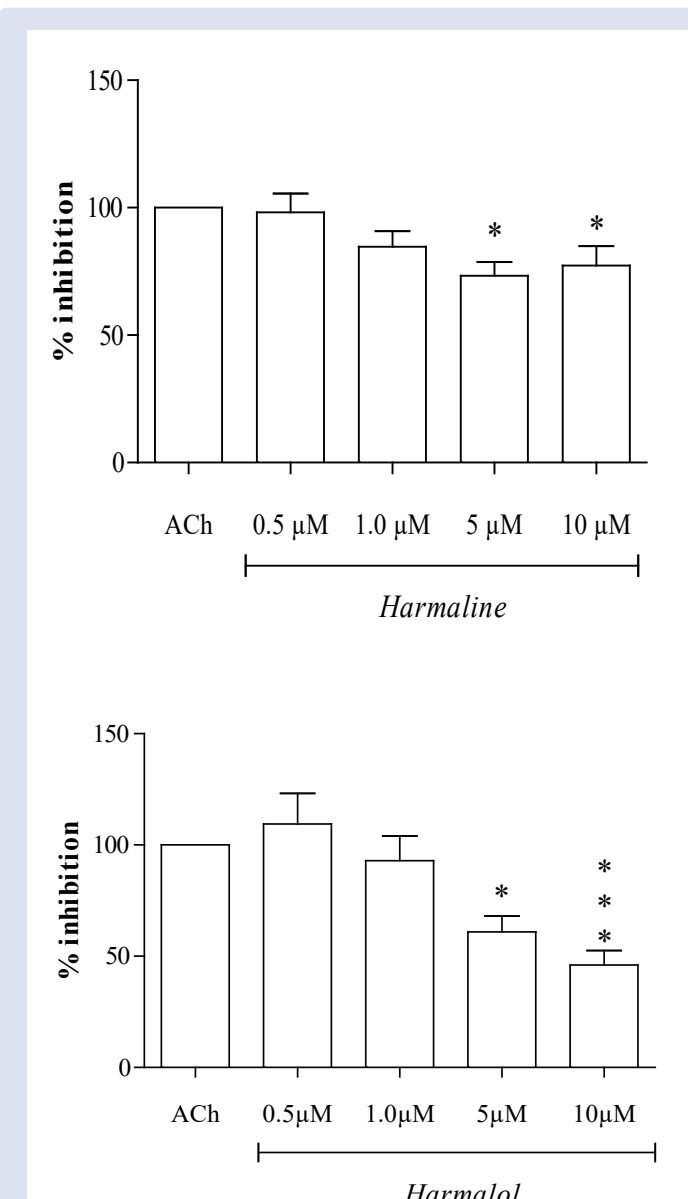

Harmalol

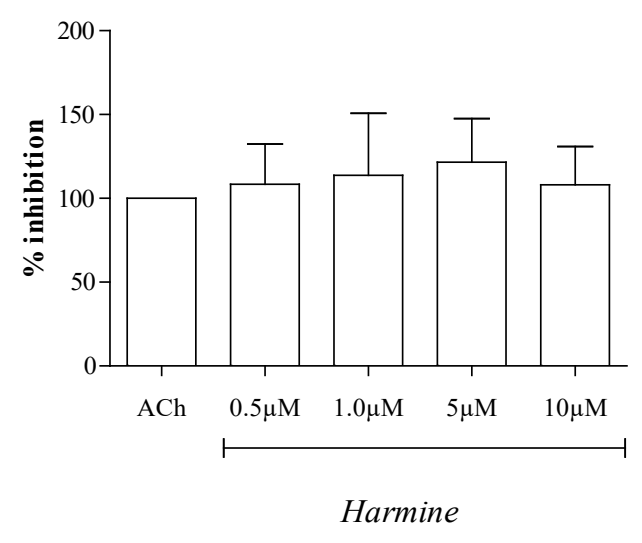

Figure 1: Effect of Harmaline, Harmalol and Harmine (0.5$10 \mu \mathrm{M})$ on Ach induced contractions of rat isolated ileum preparations. Data are mean \pm S.E.M $(n=8,8,12$ respectively in each group) and expressed as $\%$ of control tension.

${ }^{*} \mathrm{P}<0.05$, ${ }^{* * * P}<0.0001$, ANOVA followed by Dunnett's test.

\section{Effects of harmaline, harmine or harmalol on $\mathrm{KCl}$ induced ileum contraction}

The effect of harmalol, harmaline, and harmine on $\mathrm{KCl}$ induced contractions was investigated using the ileum tissue that was exposed to $\mathrm{KCl}(60 \mathrm{mM})$ solution for 30 minutes before the experiments were commenced. The percentage inhibition of contraction induced by $\mathrm{KCl}$ in the presence of each concentration of the alkaloid was calculated. As in the case of Ach-induced contraction, the ileum preparation was 
exposed to increasing concentration of harmine without showing any effect. However, harmaline at $(1$ and $5 \mu \mathrm{M})$ concentrations induced inhibition in contraction that was significant. Data are mean \pm S.E.M and expressed as $\%$ of control tension. ${ }^{\star} \mathrm{P}<0.05$ ANOVA followed by Dunnett's test (Figure 2).

Effects of harmaline, harmine or harmalol on $\mathrm{BaCl}_{2}$ induced ileum contraction

As shown in (Figure 3), harmalol was the only alkaloid that produced significant inhibitory effect on $\mathrm{BaCl}_{2}$ reducing the maximum induced contraction at $10 \mu \mathrm{M},{ }^{* *} \mathrm{P}<0.01$ (ANOVA followed by Dunnett's test). No significant decrease was observed when the preparation was pretreated with harmaline or harmine.

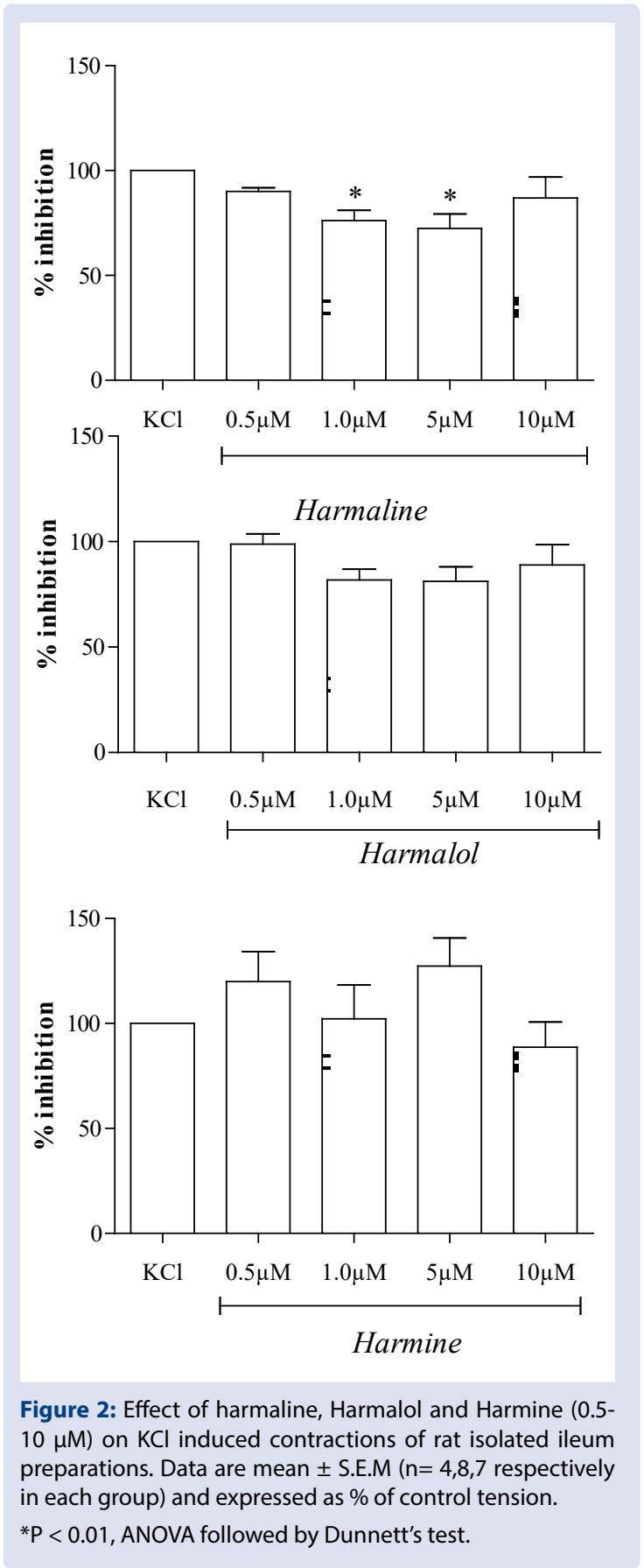

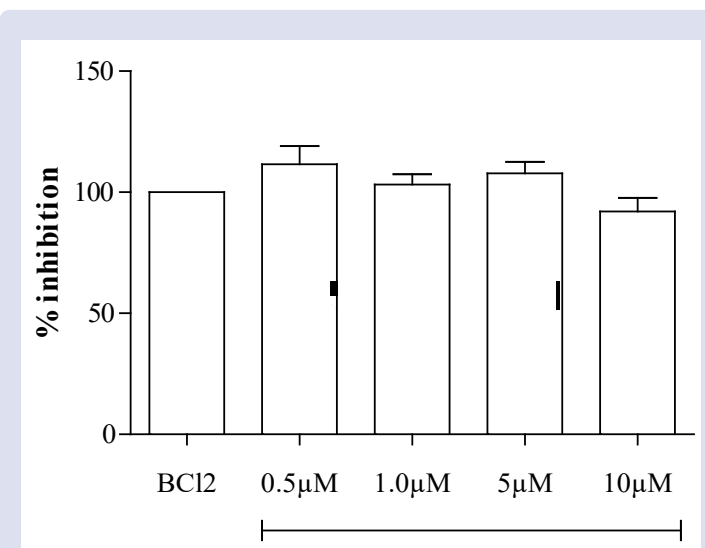

Harmaline

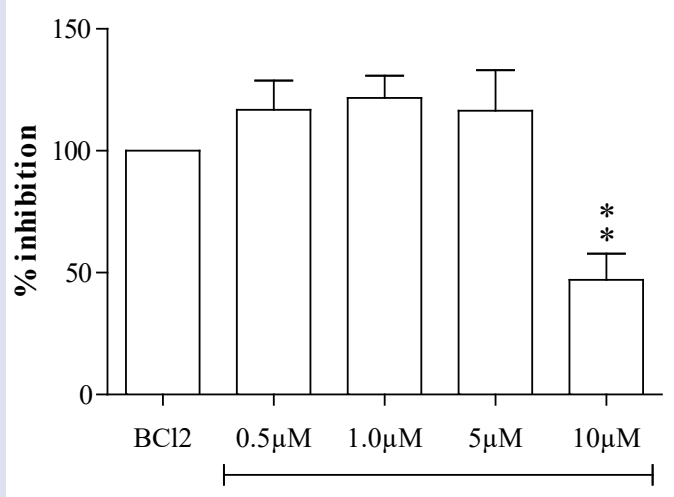

Harmalol

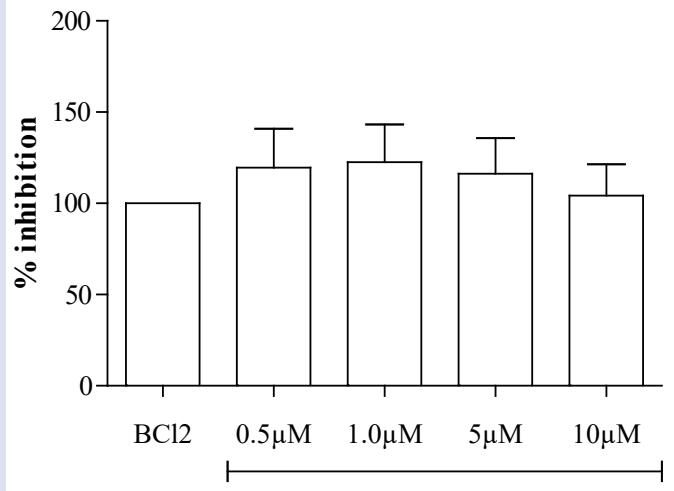

Harmine

Figure 3: Effect of Harmaline, Harmalol and Harmine (0.5$10 \mu \mathrm{M}$ ) on $\mathrm{BaCl} 2$ induced contractions of rat isolated ileum preparations. Data are mean \pm S.E.M ( $n=4,8,8$ respectively in each group) and expressed as \% of control tension.

**P $<0.01$, ANOVA followed by Dunnett's test.

\section{Solvent effect on rat ileum contraction}

The alkaloids were dissolved in 5\% dimethylsulfoxide (DMSO) in all conducted experiments therefore to determine whether the solvent alone was able to inhibit contractions. Five percent DMSO has been added to some preparations without harmalol, harmaline and harmine. The solvent had no effects on $\mathrm{KCl}$ induced contraction of the ileum (Figure 4).

\section{DISCUSSION}

Certain similarities as well as distinct difference in the antispasmodic response to the three harmala alkaloids observed on rat ileum 


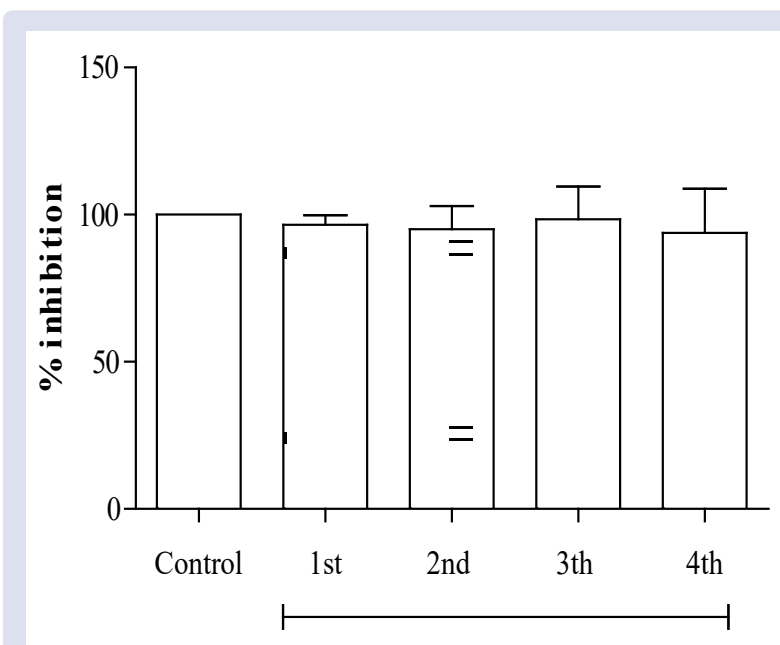

DMSO 5\%

Figure 4: Effect of DMSO (5\%) on $\mathrm{KCl}$ induced contractions of rat isolated ileum preparations. Data are mean \pm S.E.M $(n=8)$ and expressed as \% of control tension.

contractions. Harmalol, harmaline exhibited similar effect, whereas harmine was not active. Increasing concentrations of harmalol and harmaline were found to reduce the intensity of rat ileum contractions (Figures 1-3).

This finding agrees that a methoxy group on the indole nucleus, and the C3-C4 double bond (Harmine) is important for antispasmodic activity. Harmalol in which a 7-hydoxy group replaces the methoxy group of harmaine and no double bond at $\mathrm{C} 3-\mathrm{C} 4$ produces good antispasmodic effect evoked by Ach, $\mathrm{BaCl}_{2}$ and $\mathrm{KCl}$. Harmaline in which 7-methoxy group, similar like harmine but lack C3-C4 double bond also appears to be active. While harmine with both methoxy group on the indole nucleus, and the C3-C4 double bond had no effect. The order of inhibitory of the contraction induced was harmalol $>$ harmaline $>$ harmine.

The Ach, $\mathrm{KCl}$ and $\mathrm{BaCl}_{2}$ are commonly used spasmogens to detect the spasmolytic activity of intestinal smooth muscles of different compounds, drugs and plant extracts. The $\mathrm{KCl}$-evoked contractile responses are caused by depolarization of the muscle fibers through an increase of $\mathrm{K}^{+}$leading to the opening of L-type $\mathrm{Ca}^{2+}$ voltage-dependent channels. Thus, the intracellular $\mathrm{Ca}^{2+}$ concentration increases leading to the activation of the myosin light chain and contraction of the smooth muscle. ${ }^{21-23}$

Acetylcholine is considered a neurotransmitter which can cause smooth muscle contraction by activation of muscarinic receptors. Muscarinic receptors are a member of G-protein-coupled receptors found in smooth muscles. The gastrointestinal smooth muscles exhibit two main muscarinic receptors subtypes; $\mathrm{M}_{2}$ and $\mathrm{M}_{3}{ }^{24}$ The activation of muscarinic receptor enhances the release of $\mathrm{Ca}^{2+}$ leading to an increase in the intracellular $\mathrm{Ca}^{2+}$ which opens the $\mathrm{Ca}^{2+}-\mathrm{K}^{+}$channels causing membrane depolarization, increases action potential and muscle contraction. ${ }^{25,26}$ Earlier studies have suggested that in the intestinal smooth muscle, $\mathrm{BaCl}_{2}$ caused contraction through excitation of nerve cells (neuronal action) $)^{27}$ or directly acted on the smooth muscle via an increase of $\mathrm{Ca}^{2+}$ influx, ${ }^{28,29}$

In terms of structure activity relationship, the present results indicate that the $\mathrm{C} 3-\mathrm{C} 4$ double bond blocks antispasmodic activity. Functional group in the $\mathrm{C} 7$ position plays important role activity enhanced when replaced with $(\mathrm{OH})$ group as in harmalol.
Comparing the chemical structures and the inhibitory effects on ileum contractions of the harmala alkaloids, it is concluded that the presence of 7-OH group increases the inhibitory effect on intestinal smooth muscle while the presence of 6- or 7-methoxy group decrease this inhibitory activity. C3-C4 double bond blocks antispasmodic activity.

From the results, we can conclude that alkaloids $\beta$-carbolines mainly harmaline and harmalol have a spasmolytic effect on rat ileum contracted by different stimulants, $\mathrm{Ach}, \mathrm{KCl}$ and $\mathrm{BaCl}_{2}$. These results could open doors again for traditional medicinal plants in treatment of different gastrointestinal spasms.

This study also demonstrates the potency and selectivity of harmalol in the spasmolytic effect and its potential as a novel compound for the development of new drug for treatment of intestinal spasm.

\section{CONCLUSION}

The herein presented results show that harmalol and harmaline have produced a decrease in isolated rat ileum contractions, with $10 \mu \mathrm{M}$ concentration. Studies conducted in order to determine the potential mechanism of action revealed that this alkaloid inhibits both Achand $\mathrm{Ca}^{2+-}$ induced contractions. Based on these preliminary studies, it is postulated that harmalol and harmaline significantly affect the motor function of the gastrointestinal tract via mechanisms that most probably involve $\mathrm{Ca}^{2+}$ ions. However, this effect can be shown at higher concentrations.

\section{REFERENCES}

1. Shatarat A, Abuhamdah S, Al-Essa M, Mohammed F, Al-Olimat S. Pharmacological effects of Peganum Harmala $L$. root extract on isolated rat small intestine. Pharmacognosy Communications. 2014;4(3).

2. Asgarpanah J, Ramezanloo F. Chemistry, pharmacology and medicinal properties of Peganum harmala L. African Journal of Pharmacy and Pharmacology. 2012;6(22):1573-80.

3. Niroumand MC, Farzaei MH, Amin G. Medicinal properties of Peganum harmala $\mathrm{L}$. in traditional Iranian medicine and modern phytotherapy: A review. Journal of Traditional Chinese Medicine. 2015;35(1):104-9.

4. Scherrer R, Gerhardt P. Molecular sieving by the Bacillus megaterium cell wall and protoplast. Journal of Bacteriology. 1971;107(3):718-35.

5. Dube A, Misra P, Khaliq T, Tiwari S, Kumar N, Narender T. Therapeutic potential of Harmala (Peganum harmala L.) seeds with an array of pharmacological activities. Nuts and Seeds in Health and Disease Prevention. 2011;601-9.

6. Bukhari N, Choi JH, Jeon CW, Park HW, Kim WH, Khan MA, et al. (2008) Phytochemical studies of the alkaloids from Peganum harmala. Applied Chemistry. 2008;12(1):01-4.

7. Aqel M, Hadidi M. Direct relaxant effect of Peganum harmala seed extract on smooth muscles of rabbit and guinea pig. International Journal of Pharmacognosy. 1991;29(3):176-82.

8. Shapira Z, Terkel J, Egozi Y, Nyska A, Friedman J. Abortifacient potential for the epigeal parts of Peganum harmala. Journal of Ethnopharmacology. 1989;27(3):319-25

9. Karaki H, Kishimoto T, Ozaki H, Sakata K, Umeno H, Urakawa N. Inhibition of calcium channels by harmaline and other harmala alkaloids in vascular and intestinal smooth muscles. British Journal of Pharmacology. 1986;89(2):367-75.

10. Herraiz T, González D, Ancín-Azpilicueta C, Arán VJ, Guillén H. $\beta$-Carboline alkaloids in Peganum harmala and inhibition of human monoamine oxidase (MAO). Food and Chemical Toxicology. 2010;48(3):839-45

11. Fortunato JJ, Réus GZ, Kirsch TR, Stringari RB, Stertz L, Kapczinski F, et al. Acute harmine administration induces antidepressive-like effects and increases BDNF levels in the rat hippocampus. Progress in Neuro-Psychopharmacology and Biological Psychiatry. 2009;33(8).

12. Farouk L, Laroubi A, Aboufatima R, Benharref A, Chait A. Evaluation of the analgesic effect of alkaloid extract of Peganum harmala $L .:$ Possible mechanisms involved. Journal of Ethnopharmacology. 2008;115(3):449-54.

13. Berrougui H, Martín-Cordero C, Khalil A, Hmamouchi M, Ettaib A, Marhuenda $E$, et al. Vasorelaxant effects of harmine and harmaline extracted from Peganum harmala L. seed's in isolated rat aorta. Pharmacological Research. 20065;54(2):150-7. 
14. Im JH, Jin YR, Lee JJ, Yu JY, Han XH, Im SH, et al. Antiplatelet activity of $\beta$-carboline alkaloids from Perganum harmala: a possible mechanism through inhibiting PLC $\gamma 2$ phosphorylation. Vascular Pharmacology. 2009;50(5-6):14752.

15. LiY, Liang F, Jiang W, Yu F, Cao R, Ma $\mathrm{Q}$, et al. DH334, a $\beta$-carboline anti-cancer drug, inhibits the CDK activity of budding yeast. Cancer Biology \& Therapy. 2007;6(8):1204-10

16. Moloudizargari M, Mikaili P, Aghajanshakeri S, Asghari MH, Shayegh J. Pharmacological and therapeutic effects of Peganum harmala and its main alkaloids. Pharmacognosy Reviews. 2013;7(14):199.

17. Monsef HR, Ghobadi A, Iranshahi M, Abdollahi M. Antinociceptive effects of Peganum harmala L. alkaloid extract on mouse formalin test. J Pharm Pharm Sci. 2004;7(1):65-9.

18. Lamchouri $F$, Settaf $A$, Cherrah $Y$, Hassar M, Zemzami $M$, Atif $N$ et al In vitro cell-toxicity of Peganum harmala alkaloids on cancerous cell-lines. Fitoterapia. 2000;71(1):50-4.

19. Shi CC, Liao JF, Chen CF. Spasmolytic Effects of Three Harmala Alkaloids on Guinea-Pig Isolated Trachea. Pharmacology \& Toxicology. 2001;89(5):259-64.

20. Hider RC, Smart L, Suleiman MS. The effect of harmaline and related $\beta$-carbolines on the acetylcholine-stimulated contractions of guinea-pig ileum. European Journal of Pharmacology. 1981;70(4):429-36.

21. Shi CC, Liao JF, Chen CF. Spasmolytic Effects of three harmala alkaloids on guinea-pig isolated trachea. Pharmacology \& Toxicology. 2001:89(5):259-64.
22. Karaki H, Ozaki H, Hori M, Mitsui-Saito M, Amano K, Harada K, et al. Calcium movements, distribution and function in smooth muscle. Pharmacol Rev. 1997;49:157-230

23. Reddy H, Watson N, Ford APDW, Eglen RM. Characterization of the interaction between muscarinic M2 receptors and beta adrenoceptorsubtypes in guineapig isolated ileum. Br J Pharmacol. 1995;114:49-56.

24. Komori S, Bolton TB. Role of G-proteins in muscarinic receptor inward and outward currents in rabbit jejunal smooth muscle. The Journal of Physiology 1990;427(1):395-419.

25. Reddy H, Watson N, Ford APDW, Eglen RM. Characterization of the interaction between muscarinic $M 2$ receptors and $\beta$ - adrenoceptor subtypes in guineapig isolated ileum. British Journal of Pharmacology. 1995;114(1):49-56.

26. Bohn LM, Raehal KM. Opioid receptor signaling: relevance for gastrointestina therapy. Curr Opin Pharmacol. 2006;6(6):559-63.

27. Toh CC. Experiments on the barium contraction of the guinea-pigs ileum. Journal Of Physiology-London. 1951;114(3):33

28. Clement JG. BaCl2-induced contractions in the guinea pig ileum longitudina muscle: role of presynaptic release of neurotransmitters and $\mathrm{Ca} 2+$ translocation in the postsynaptic membrane. Canadian Journal of Physiology and Pharmacology. 1981;59(6):541-7.

29. Hardcastle J, Hardcastle PT, Noble JM. The effect of barium chloride on intestinal secretion in the rat. The Journal of Physiology. 1983;344(1):69-80.

\section{GRAPHICAL ABSTRACT}

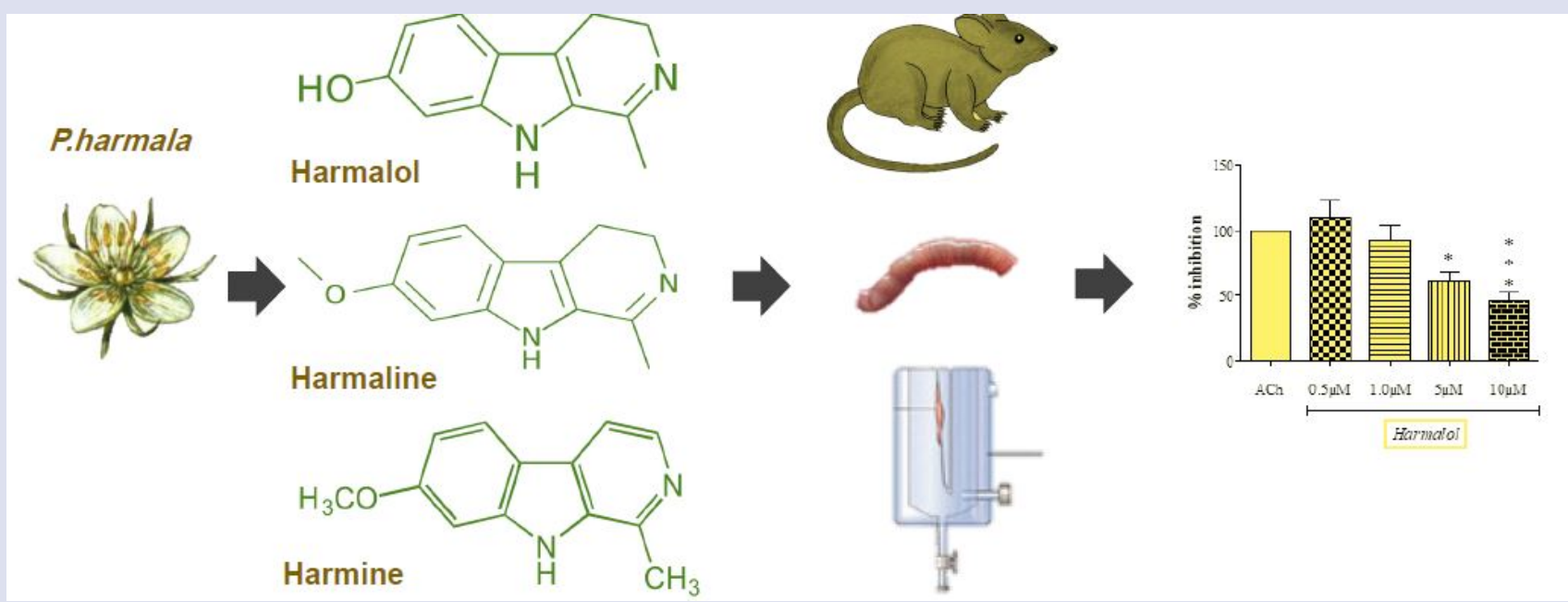

\section{ABOUT AUTHORS}

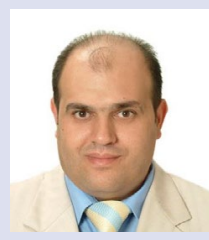

Amjad T. Shatarat, MD. Ph.D. Associate professor at the Department of Anatomy and Histology, School of Medicine, The University of Jordan. Currently, chairman of Anatomy department. Graduated from Crimea State Medical University/Russia in 2000. Then finished the PhD program from The University of Nottingham/ UK in 2011. Teaching Anatomy, Histology and Embryology Courses to Medical, Dental, Pharmacy, Rehabilitation and Nursing students. Focusing on Research activities related to blood vessels, role of different medicinal plants on the smooth muscles, anatomical variations and radiology. He Participated in many National and International conferences and had more than 20 publications.

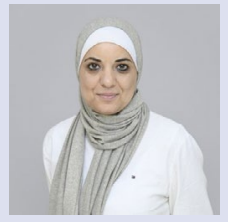

Dr. Sawsan Abuhamdah is a Jordanian registered pharmacist, has completed her PhD from Durham University, UK and postdoctoral studies from Granada Medical School, Department of Pharmacology, associate professor at the faculty of pharmacy, University of Jordan, and now working at college of Pharmacy, Al Ain University, Abu Dhabi, UAE.

Dr. Abuhamdah has published many original research articles in peer-reviewed journals and participated in the preparation of many symposium abstracts. Dr. Abuhamdah is a member of the British Pharmacological Society (BPS), British Neuroscience Association (BNA), and Jordan Pharmaceutical Association. 


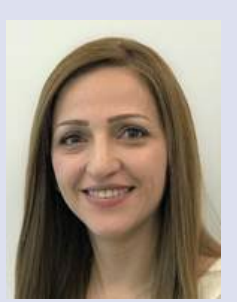

Dr. Alefishat received her Ph.D. from the University of Nottingham, UK in 2011, her thesis focused on the cardiovascular system. She works as an associate professor and assistant dean for PharmD Program and Hospital Affairs at School of pharmacy in the University of Jordan. Dr. Alefishat published several papers in peer reviewed international journals, and have collaborations with colleagues from the United States and the United Kingdom. Her research is in the area of circadian disruption and its relationship with insulin resistance, vitamin $\mathrm{D}$ deficiency, cardiovascular and metabolic diseases, and inflammation.

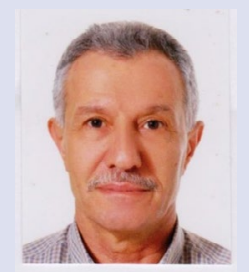

Mohamed K. Al-Essa, MD. Ph.D. Associate professor in the Department of Physiology and Biochemistry at the Faculty of Medicine/The University of Jordan. Graduated from Medical College of Virginia Commonwealth University/USA in 1999. Teaching Medical Physiology Courses to Medical, Dental, Pharmacy, Rehabilitation and Nursing students. Focusing on Research activities related to regulatory mechanisms, stem cells and development of assay methods. He Participated in many National and International conferences and had more than 15 publications.

Rima K. Altaweel, research assistant in the Department of Anatomy and Histology at the Faculty of Medicine/ The University of Jordan. Graduated from University of Jordan, rehabilitation faculty/Jordan in 2012. Then finished the Master program of Anatomy and Histology from The University of Jordan/Jordan in 2019. Assist in teaching Anatomy practical labs to Medical, Pharmacy, and Rehabilitation students. Focusing on Research activities related to Anatomy, Histology and Rehabilitation field.

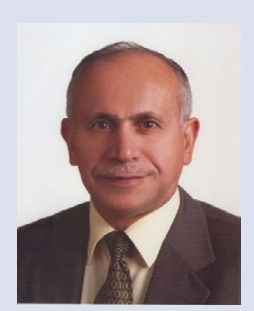

Faisal I. Mohammed is a professor of Physiology at the University of Jordan. Currently, he is the Chairman of the department of physiology and biochemistry. He graduated from University of Jordan medical school, then finished his PhD program from St. Louis University, USA. He participated in teaching physiology to all medical professional schools' students. His special interests are topics related cardiovascular physiology and smooth muscle physiology.

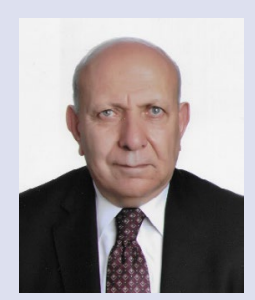

Darwish Badran is a professor of Anatomical Sciences at the University of Jordan. Currently, he is the Dean of the Faculty of Medicine at the Hashemite University, Jordan. Graduated from Glasgow University, 1992. He participated in teaching Anatomy, Histology, Embryology and Neuroanatomy to Medical and Dentistry Students for more than 25 years. He participated in developing Anatomical Sciences curricula in many Medical Schools. He participated in many National, Regional and International conferences and has more than 60 published papers. His special interests are topics related to Clinical Anatomy and Histology.

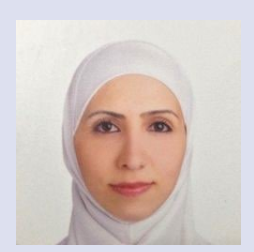

Hanan Jafar holds a PhD in "Stem Cell Biology", an MSc in "Anatomy and Histology", and a DDS in "Dental Sciences" from the University of Jordan. Shre is jointly appointed as faculty member at the School of Medicine and Assistant Director at the Cell Therapy Center (CTC), University of Jordan.

Cite this article: Shatarat AT, Abuhamdah S, Alefishat E, Al-Essa M, Altaweel RR, Mohammed F, et al. Effects of Beta-Carboline Alkaloids of Peganum Harmala on Induced Rat Ileum Contractions. Pharmacog J. 2020;12(2):260-5. 